\title{
스리랑카 9월 원조동향
}

선진원조국 및 국제기구 등의 9월중 스리랑카 원 조동향은 아래와 같음.

\section{1 일본}

$\square \mathrm{JICA}$ 의 IT 분야 교육훈련 사업

- IT 산업 분야의 인적자원 역량개발 지원 및 청 년층 고용기회 창출을 위하여 US\$57백만 규모 의 IT 분야 교육훈련 사업을 향후 5 개년간 실시 예정

- 스리랑카 정부는 1998년을“ 정보통신의 해 (Year of Information Technology)로 선포하 고 IT 분야의 통합적 인력개발 계획 추진

동ㅇㅇ 사업의 일환으로 JICA 기술협력 사업을 통해 콜롬보대학 컴퓨터 학과(UCSC)에 웹기반 훈련과 정 개설('02 '04)

- 상기 사업성과를 제고코자 USCS에 e learning 기술교육을 위한 일련의 훈련 프로그램을 마련 하고, JICA와 USCS간 5개년 협정 체결
- 향후 5년간 매년 개설되는 훈련과정을 통해 스 리랑카 내국인 160 명과 외국인 80 명 등 총 240 명의 IT 분야 전문인력을 양성할 수 있을 것으로 기대됨.

(1) In- country Training Programmes(ICTP) : 스리 랑카 국적의 $\Pi$ 분야 종사자 대상

प Third- country Training Programmes(TCTP) : 인도, 방글라데시, 파키스탄, 몰디브, 부탄, 네팔, 베트남, 라오스, 캄보디아, 미얀마, 몽골, 이란, 아 프가니스탄, 케냐, 우간다 및 탄자니아 등 아시아/ 아프리카 지역 16 개국 $\Pi$ 인력

$\square \mathrm{JBIC}$ 의 지뢰제거 사업

- 스리랑카 북부 자프나, 킬리노츠치, 바부니야 및 마나 지역과 동부 바티깔로아 지역을 대상으 로 지뢰제거 활동 지원, 관련 장비 지원 등 지뢰 제거 사업 추진

- 총 US\$1,845,721이 투입되는 금번 사업은 Denish Demining Group, HALO Trust, 
Mines Advisory Group, Norweign People's Aid, Swiss Foundation for Mine Action 등 5 개 국제 NGO에 의해 추진되며, 지뢰제거 현장 에의 원활한 전기 공급을 위한 전선망 구축사업 (electricity power line project)도 별도 지원

$\square$ Puttlam 지역 Grass Roots Human Security Project

- 지속가능한 인적자원 개발 및 농업을 통한 빈곤 퇴치를 목적으로 푸트람 지역에서 추진해 온 US\$66,233 규모의 “ Human Security Project"가 성공적으로 종료됨.

- 물탱크 지원을 통한 관개용수의 원활한 공급 및 농로(農路) 개선 등을 통해 수확량 증대 및 물류 여건을 향상시켰으며, 이는 곧 1,700 여 농가의 수익증대로 이어짐.

- 일본은 지난 3년간 US\$8백만 규모의 상기와 같 은 "Human Security Project”를 스리랑카 전 역에서 추진해 옴.

\section{2. 중국}

화력발전소 설비이전을 위한 차관 지원

- 화력발전소(300MW 규모) 설계 및 건설 (design- build- transfer)을 위한 양국간 MoU 체결

- 2005년 10월 2009년간 추진 예정인 동 사업은 단일규모로는 역대 최고로 총 US\$380백만 투 입 예정(20년 거치 상환)

\section{3. 미국}

$\square$ USAID의 Tsunami Reconstruction Programme (TRP)

- 총 US\$33백만 규모의 대규모 인프라 구축

- Arugam Bay에 $700 \mathrm{~m}$ 길이의 최신공법 교량 건설

- Pottuvil 지역에 식수 및 위생시설 개선 지원

- 관광산업 개발을 위한 지역사회 컨설팅 제공

- 14 개 직업훈련 시설 복구

그내의 모델학교 지원, 직훈 관련 기자재 지원 및 교과과정 개발을 위한 기술지원 포함

- Hikkaduwa, Mirissa, Dondra 지역 어촌마을 개선 및 지역 주민 참여 확산을 통한 해안지역 관리 사업 등

\section{UNDP}

$\square$ UNDP 's Transition Programme

- UNDP는 분쟁 후유증으로 고통 받고 있는 스리 랑카 동북부 지역에 대한 인도적, 재건복구 지 원을 통해 평화정착을 도모코자 스리랑카 농어 촌지역의 전통적 경제 부문인 농업, 축산 및 어 업부문 지원사업을 수행하고 있음.

- 동 사업의 일환으로 Vavuniya 지역 가축육종 협동조합에 우유가공 및 판매촉진을 위하여 오 토바이, 트레일러, 우유포장용 캔 등을 CIDA의 재정지원으로 지원함.

$\square$ 부패방지 노력 지원

- UNDP는 스리랑카 CIABOC(Commission to Investigate Allegations of Bribery or 
Corruption)를 통해 공공 및 민간 부문에서의 투명성과 책임성 제고 및 부패방지 노력을 지원 하고 있음.

- 공공부문 watchdog 그룹 운영, 시민 대상 의식 화 교육 및 $\mathrm{CIABOC}$ 의 운영과 전문인력 양성 등 을 위하여 총 US\$125,000이 투입될 예정임.

\section{5. $10 \mathrm{M}$}

$\square$ 쓰나미 피해자 지원을 위한 전산 D/B 센터 구축

- 쓰나미 피해 지역 주민들의 개별적인 수요를 파 악하고 구호물품 전달 및 재건사업 수행 과정에 서의 신속성 강화 및 중복지원 지양 등을 목적 으로 전산 $\mathrm{D} / \mathrm{B}$ 센터 구축

- 총 US\$1.2백만이 투입되는 금번 사업은 ECHO(European Commission Humanitarian Aid Office)에서 재정 지원

- 동 전산 시스템 구축은 재건복구 사업에 관여하 고 있는 모든 관계자들이 효과적이고 효율적인 재건 정책을 수립하는 데 있어서도 긍정적인 역 할을 할 수 있을 것으로 기대

$\square$ 쓰나미 피해지역 청년 대상 워크숍 개최

- IOM은 USAID와 일본 정부의 후원으로 쓰나미 피해지역 청년들을 대상으로 취업설명회와 인 신매매, HIV/AIDS, 불법이민 및 여타 위험으로 부터 자신을 보호하는 방법 등을 설명하는 워크 솝 개최

$\square$ 쓰나미 피해지역 임시 주택 지원

- 일본, 그리스, 중국 및 $\mathrm{ECHO}$ 등의 재정지원으 로 암파라, 마타라, 트린코말리, 콜롬보, 감파하,
칼루타라 및 바티깔로아 지역에 총 3천채의 임 시주택(약 2년 수명) 지원

- 금번 지원으로 약 86천 세대 가족들에게 혜택을 줄 것으로 기대되며, IOM은 지역사회의 결속력 강화 및 쓰나미 피해지역 주민들의 정서함양등 을 위하여 임시주택을 지원하는 각 지역별로 유 치원, 청소년 클럽, 티센터, 봉제센터, 도서관 및 운동장 등을 포함하여 지원하고 있음.

6. 쓰나미 피해복구 임시주택 지원사업 중간 점검 $\square \mathrm{UN}$ 기구 및 많은 NGO들의 지원을 통해 50,000 여채의 임시 주택이 건축되었으며, 4,050채의 주 택이 건축중임.

$\square 5$ 만여채 임시주택 지원으로 많은 가구들이 난민 촌 생활에서 벗어나 기초위생시설, 전기, 수도, 인 접도로, 여가시설 등이 마련된 보다 편안하고 안 정된 공간에서의 생활이 가능하게 되었으며, 아이 들은 학교에 정상적으로 등교하고, 상당수 가구 의 가장들이 일자리를 찾게 되었음.

- 쓰나미피해 직후, 773 개 이재민 캠프에 232,000 세대 552,000명이 거주하였으나, 2005년 8월 15일 현재 42개 캠프에 1,589 세대 7,250 명으로 감소

- 5만여 임시주택 중, 트린코말리· 바티깔로아 암파라 자프나 킬리노츠치 물라티보 등 동 북부 지역에 약 38,600 채가 지원되었으며, 골. 칼루타라 함반토타 및 마타라 등 남부 지역에 약 12,260 채가 지원됨. 
<2005. 9월 국/기관별 원조 총괄표>

\begin{tabular}{|c|c|c|c|c|}
\hline 국/기관명 & 지원액 & 사업내용 & 대상지역 & 비 고 \\
\hline \multirow{3}{*}{ 일 본 } & US $\$ 57$ 백만 & IT 분야 5개년 교육훈련 사업 & 콜롬보(콜롬보 대학) & - 사업수행 : JICA \\
\hline & US\$66,233 & $\begin{array}{l}\text { Human Security Project } \\
\text { - 농촌지역 환경개선을 통한 } \\
\text { 농가 소득증대사업 }\end{array}$ & 푸트람 & $\begin{array}{l}\text { - 사업수행 : 스리랑카 CTF } \\
\text { (Community Trust Fund) }\end{array}$ \\
\hline & US $\$ 1,845,721$ & $\begin{array}{l}\text { 동북부 지뢰제거 사업 } \\
\text { - 지뢰제거, 장비지원 및 } \\
\text { 대상지역에 대한 전선 연결 등 }\end{array}$ & $\begin{array}{c}\text { 자프나, 킬리노츠치, } \\
\text { 바부니야, 마나, 바티깔로아 }\end{array}$ & $\begin{array}{l}\text { - 사업수행 : } \\
\text { DDG, MAG 등 5개 INGO }\end{array}$ \\
\hline \multirow[b]{2}{*}{ 중 국 } & US\$10백만 & $\begin{array}{l}\text { 중 스 우정촌 조성 } \\
-500 \mathrm{sq} \text { 규모의 침실 } 2 \text {, 거실, 화장실, } \\
\text { 부억 등의 시설을 갖춘 주택 건축 }\end{array}$ & 골 & $\begin{array}{l}\text { - 사업수행 : } \\
\text { China Charity Federation }\end{array}$ \\
\hline & US $\$ 380$ 백만 & $\begin{array}{l}\text { 화력발전소 설비이전 차관사업 } \\
\text { - 2005년 10월 2009/300MW } \\
\text { 규모/20년 거치 상환 }\end{array}$ & 노로츠초라이 & $\begin{array}{l}\text { - 사업수행 : 중국- China National } \\
\text { Machinery \& Equipment Import } \\
\text { \& Export Corporation } \\
\text { 스리랑카 Ceylon Electricity Board }\end{array}$ \\
\hline \multirow{6}{*}{ 미 국 } & US\$33백만 & $\begin{array}{l}\text { 쓰나미 재건 프로그램 } \\
\text { - 교량, 식수/위생 설비, 직훈원, } \\
\text { 해안 개발 등 대규모 Infrastructure } \\
\text { 지원사업 }\end{array}$ & $\begin{array}{c}\text { 포뚜빌, 히까두와, 미리사, } \\
\text { 돈드라 등 지역 }\end{array}$ & - 사업수행 : USAID \\
\hline & US $\$ 422,800$ & 국제공항 개선 사업 & 네곰보 & \multirow{5}{*}{$\begin{array}{l}\text { - 사업수행 : USTDA } \\
\text { (US Trade \& Development Agency) }\end{array}$} \\
\hline & US $\$ 356,000$ & $\begin{array}{l}\text { 태양열 이용 지역사회 용수공급 } \\
\text { 시범사업 }\end{array}$ & 함반토타 & \\
\hline & US $\$ 475,000$ & $\begin{array}{l}\text { 콜롬보- 외곽간 교통망 개선을 위한 } \\
\text { 개발조사 사업 }\end{array}$ & 콜롬보 및 외곽 & \\
\hline & US $\$ 375,000$ & $\begin{array}{l}\text { 재난관리센터(DMC) ICT 시스템 } \\
\text { 구축 사업 }\end{array}$ & - & \\
\hline & US $\$ 398,000$ & 자연재해 조기경보 시스템 구축 사업 & - & \\
\hline 노르웨이 & Rs. 450백만 & $\begin{array}{l}\text { 쓰나미 피해지역 학교 건축, 보수, } \\
\text { 위생시설 등 개선 }\end{array}$ & $\begin{array}{l}\text { 마타라, 암파라, 함반토타, } \\
\text { 바티깔로아, 트린코말리 }\end{array}$ & $\begin{array}{l}\text { - 사업수행 : 노르웨이난민위원회 } \\
\text { (NRC; Norwegian Refugee Council) }\end{array}$ \\
\hline 몰 타 & US $\$ 334,800$ & $\begin{array}{l}\text { 소규모 Malta Villge 조성 } \\
\text { - 침실 } 2 \text {, 거실, 화장실, 부억 등 } \\
\text { 시설을 갖춘주택 } 62 \text { 채 건축 }\end{array}$ & 함반토타 & $\begin{array}{l}\text { - 사업수행 : 몰타적십자사 } \\
\text { (Malta Red Cross Society) }\end{array}$ \\
\hline 헝가리 & Rs.300백만 & $\begin{array}{l}\text { Hungarian Village 조성 } \\
\text { - } 600 \text { sq.ft.의 주택 } 180 \text { 채 건축 } \\
\text { - 유치원 } 2 \text { 개소, 마을 회관, 고아원, } \\
\text { 메디칼 센터(기자재 포함), 운동장 및 } \\
\text { 놀이터 각 } 1 \text { 개소 건축 }\end{array}$ & 골 & $\begin{array}{l}\text { - 사업수행 : 헝가리적십자사 } \\
\text { (Hungarian Red Cross) }\end{array}$ \\
\hline UNDP & US $\$ 125,000$ & $\begin{array}{l}\text { 부패방지 노력 지원 } \\
\text { - watchdog 그룹 운영, 시민대상 } \\
\text { 의식화 교육 및 전문인력 양성 등 }\end{array}$ & 전국 & - 사업수행기관 : CIABOC \\
\hline \multirow[b]{2}{*}{$10 \mathrm{M}$} & US\$12백만 & 쓰나미 피해지원 전산시스템 구축 & 전국 & - ECHO에서 재정 지원 \\
\hline & - & 쓰나미 피해지역 임시주택 지원(3천채) & $\begin{array}{l}\text { 암파라, 마타라, 트린코말리, } \\
\text { 콜롬보, 감파하, 칼루타라 등 }\end{array}$ & $\begin{array}{l}\text { - 일본, 그리스, 중국, ECHO의 } \\
\text { 재정 지원 }\end{array}$ \\
\hline
\end{tabular}


7. US\$50억 규모 원조사업 현재진행중

$\square$ 건당 Rs.500백만 규모의 100 개 이상의 개발사업, 약Rs.4,000억 규모의 원조사업이 진행중임.

$\square$ 도로, 에너지, 식수, 상/하수, 농업, 플랜테이션 경 작, 어업 등 사회 각 부문에서 다양한 종류의 프로 젝트가 진행중이며, 국가 전역에 걸친 기간산업개 발이 주를 이루고 있음.

$\square$ 동 프로젝트들은 원조자금으로 추진중이나, 실상 그 대부분은 장기 차관 사업인바, 동 개발사업들 의 사업진행 상황이나 예산집행 과정에 대한 모 니터링의 중요성이 높아지고 있으며, 현재 재정기 획부(Ministry of Finance and Planning) 산하 에“ Foreign Aid and Budget Monitoring Department"가 조직되어 관련 업무를 진행중에 있음.

- 현재 US\$5백만 이상의 프로젝트들에 대하여는 웹기반의 모니터링 시스템을 구축, 운영중에 있 으며, 각 사업별 구체적인 사업계획 및 일정과 월별 사업추진 현황이 기록되어 있음.

$\square 2007$ 교육개혁 추진 : IT 부문 교육 활성화가 중 점 과제

\section{- 초등교육 부문}

구ㅅㅜㅏㄱ 등 일부 과목에 대하여 영어진행 수업 도입

ㅁ싱할라 및 타밀 2개 언어 교육싱할라인에게는 타 밀어 별도 교육, 타밀인에게는 싱할라어 별도 교육)

ㅁ현재 국제학교 및 일부 사립학교에서 실시하고 있 는 $\Pi$ 교육 확산

\section{- 중등교육 부문}

ㅁ화학, 물리 및 생물 과목 도입(영어 또는 싱할라어
로 교육)

ㄱ CD 및 $S / N$ 어플리케이션을 통한 읽기 수업 등 도입

- 고등교육 부문

ㅁ 컴퓨터 사용 장려를 위하여 모든 교과과정 및 교과 활동과 관련한 CD 등 SOFT 카피 형태의 교육자 료 제공

- 학교 기반 관리

ㅁ 교장 1인의 정책결정에 의존하던 과거의 학교경영 에서 나아가 동문, 학부모, 선임교사 및 지역사회 지도자 등으로 구성된 학교위원회를 조직하고, 동 조직을 통한 학교경영 추진

- 학교환경 미화

ㅁ 학교 기간시설 개선은 물론, 현대화된 인테리어 및 신가구 등 지원을 위한 별도 예산 배정.

[자료 : 주스리랑카 KOICA사무소] 